\title{
ANALISA PENGARUH DINDING GESER PADA STRUKTUR BANGUNAN HOTEL BUMI MINANG AKIBAT BEBAN GEMPA
}

\author{
Fauzan $^{1}$, Zaidir $^{2}$, Dwi Putri Nengsi ${ }^{3}$, Indri Miswar ${ }^{4}$
}

\begin{abstract}
ABSTRAK
Sumatera Barat merupakan daerah rawan gempa. Pasca gempa 30 September 2009 lalu, banyak bangunan bertingkat, baik bangunan pemerintah maupun swasta mengalami rusak berat. Salah satu bangunan yang mengalami kerusakan dan kehancuran pada elemen struktural dan non-struktural adalah gedung Hotel Bumi Minang. Oleh karena itu, struktur bangunan harus direncanakan tahan terhadap gempa. Perencanaan struktur bangunan terhadap gempa dapat dilakukan dengan pemberian dinding geser pada struktur bangunan tersebut. Penggunaan sistem struktur dinding geser dalam menahan gaya lateral yang bekerja pada bangunan sangat efektif, hal ini disebabkan dinding yang terdapat pada sistem struktur dinding geser ini berfungsi untuk menyebarkan gaya luar yang bekerja pada struktur.

Pada penelitian ini membandingkan struktur bangunan Hotel Bumi Minang dengan dinding geser dan tanpa dinding geser. Ada 4 parameter yang digunakan yaitu, tipe 1 (struktur bangunan tanpa dinding geser), tipe 2 (struktur bangunan dengan dinding geser pada daerah lift lantai $1 \& 2$ ), tipe 3 (struktur bangunan dengan dinding geser pada daerah lift sampai lantai atap) dan tipe 4 (struktur bangunan dengan dinding geser pada daerah lift sampai lantai atap dan di sudut sekeliling bangunan). Selanjutnya dianalisa hasil deformasi dan gaya dalam bangunan untuk mengetahui pengaruh penggunaan dinding geser pada struktur bangunan akibat beban-beban yang bekerja, termasuk beban gempa.
\end{abstract}

Kata Kunci : Gempa, dinding geser, deformasi, gaya dalam.

\section{1. PENDAHULUAN}

Gempa bumi merupakan suatu fenomena alam yang tidak dapat dihindari, tidak dapat diramalkan kapan terjadi dan berapa besarnya, serta akan menimbulkan kerugian baik harta maupun jiwa bagi daerah yang ditimpanya dalam waktu relatif singkat (Elan Adrayazi, 2006).

Indonesia merupakan kawasan dengan intensitas kegempaan yang aktif di dunia, karena di wilayah ini melintas Jalur Circum Pasifik dan Jalur Hindia - Himalaya. Selain itu, disebabkan karena letak Indonesia yang berada pada batas lempeng Eurasia, India dan lempeng Pasifik. Sehingga bangunan yang ada di Indonesia harus benar-benar didesain khusus untuk menahan gempa sesuai peraturan yang ada.

Gempa tektonik yang terjadi pada tanggal 30 September 2009 lalu telah mengakibatkan berbagai kerusakan baik sarana maupun prasarana fisik serta korban jiwa pada berbagai daerah di Provinsi Sumatera Barat. Menurut data dari USGS, pusat gempa berlokasi $57 \mathrm{~km}$ barat daya Pariaman dengan kekuatan 7,6 SR dan kedalaman $71 \mathrm{~km}$. Daerah yang paling parah kena dampak gempa ini adalah Kabupaten Padang Pariaman, Kota Padang, Kab. Agam dan Kab. Pesisir Selatan.

\footnotetext{
${ }^{1}$ Staf Pengajar Jurusan Teknik Sipil Fakultas Teknik Universitas Andalas, e-mail: fauzanrn@yahoo.com

${ }^{2}$ Staf Pengajar Jurusan Teknik Sipil Fakultas Teknik Universitas Andalas, e-mail: zaidir@ft.unand.ac.id

${ }^{3}$ Staf Engineer Klinik Konstruksi Pusat Studi Bencana Universitas Andalas, e-mail: dwiputrinengsi@gmail.com

${ }^{4}$ Staf Engineer Klinik Konstruksi Pusat Studi Bencana Universitas Andalas, e-mail: indri_miswar@yahoo.co.id
} 
Khusus kota Padang, pasca gempa 30 September 2009 yang lalu, banyak bangunan bertingkat (engineered buildings) baik milik pemerintah maupun swasta mengalami kerusakan total. Pada sejumlah bangunan bertingkat lainnya terjadi kerusakan yang serius pada elemen strukturnya. Salah satu bangunan yang mengalami banyak kerusakan dan kehancuran, baik pada elemen struktural maupun pada bagian non-struktural adalah gedung Hotel Bumi Minang Padang. Pada struktur bangunan tinggi biasanya digunakan dinding geser untuk menahan gaya geser akibat gempa yang terjadi yang pada prinsipnya adalah meningkatkan kekuatan struktur terhadap gaya lateral (ke samping) yang umumnya tidak memadai (Rina Mustika Raya, 2006). Posisi dinding geser ini bisa diletakkan di tengah-tengah bangunan (inti atau core) ataupun juga diletakkan di ujung-ujung gedung. Dinding ini biasanya menerus dari dasar bangunan hingga bagian atas dari struktur bangunan sehingga gaya yang dominan adalah gaya lateral atau biasa disebut dengan tall building. Untuk merancang struktur bangunan tahan gempa yang harus diperhatikan adalah struktur harus kuat dan mampu berubah bentuk (deformasi).

Penelitian ini bertujuan untuk melihat pengaruh penggunaan dinding geser dan membandingkannya dengan struktur banguan tanpa dinding geser pada bangunan Hotel Bumi Minang Padang (Gambar 1) terhadap deformasi dan gaya dalam yang terjadi. Manfaatnya dapat dijadikan acuan umum untuk pembangunan struktur gedung dengan spesifikasi yang sama. Sehingga diperoleh perhitungan struktur yang aman.

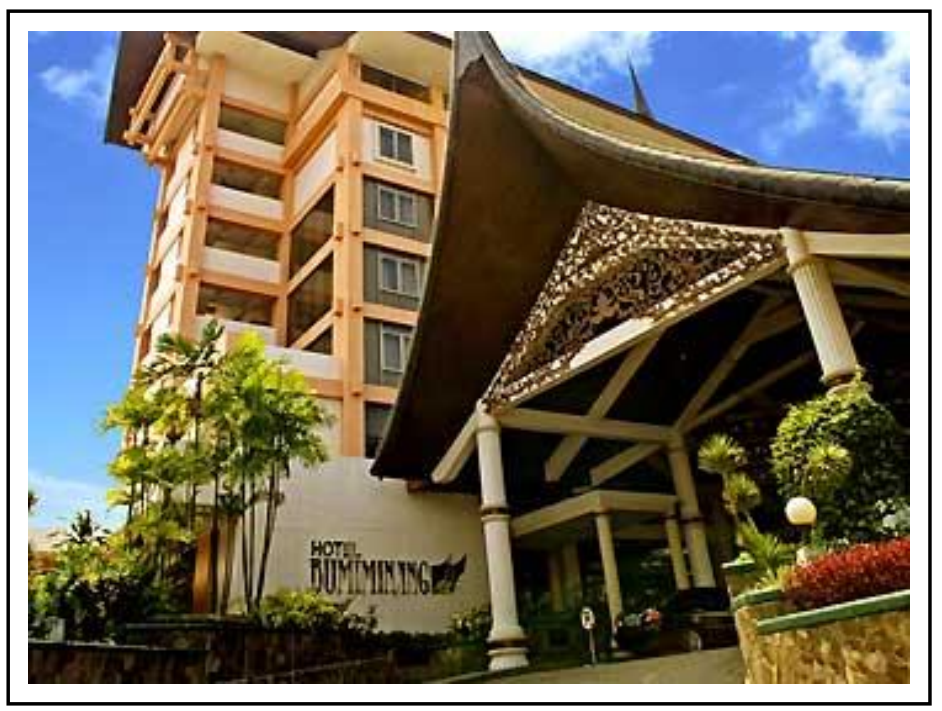

Gambar 1. Bangunan Hotel Bumi Minang Padang

\section{PERMODELAN DAN PERHITUNGAN STRUKTUR}

Pada penelitian dilakukan analisis terhadap empat tipe bangunan, yaitu :

- Tipe 1 : Bangunan tanpa dinding geser (Gambar 2.a)

- Tipe 2 : Bangunan dengan dinding geser pada daerah lift 1t. 1 dan 1t. 2 (Gambar 2.b)

- Tipe 3 : Bangunan dengan dinding geser pada daerah lift penuh sampai ke lantai atap (Gambar 2.c)

- Tipe 4 : Bangunan dengan dinding geser pada daerah lift penuh sampai ke atap dan di tiap sudut bangunan (Gambar 2.d)

Struktur yang akan dianalisis berupa struktur beton bertulang delapan lantai. Bangunan berbentuk tidak simetris dan tipikal dengan dimensi bangunan ukuran $80 \mathrm{~m} \times 17 \mathrm{~m}$. 

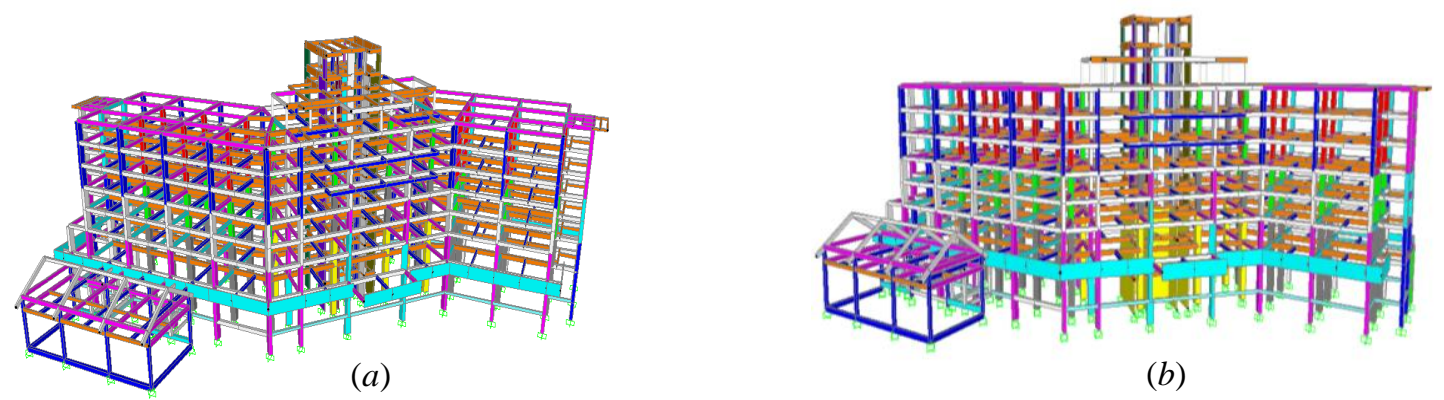

(b)
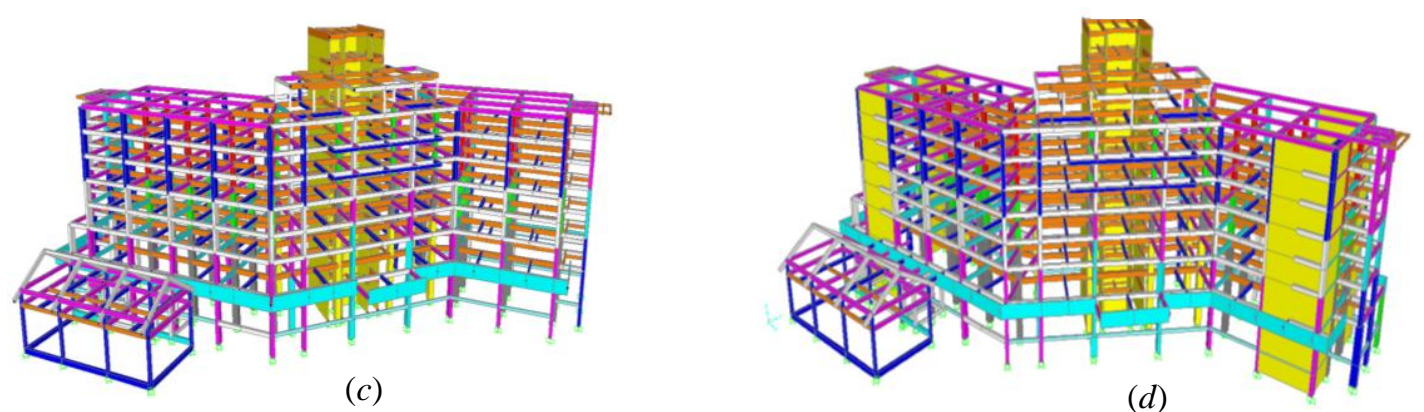

Gambar 2. Permodelan Struktur Bangunan Tiga Dimensi (3D) (a). Tipe 1, (b). Tipe 2, (c). Tipe 3 dan $(d)$. Tipe 4

Data teknis bangunan yang digunakan adalah sebagai berikut :

1. Bentuk struktur bangunan digunakan gedung Hotel Bumi Minang Padang dengan dimensi komponen-komponen utama seperti balok, kolom dan pelat menggunakan dimensi yang sudah ada.

2. Mutu beton yang digunakan untuk struktur atas K-300 dan mutu baja tulangan $f_{y}=390 \mathrm{MPa}$ (ulir) dan $f_{y}=240 \mathrm{MPa}$ (polos).

3. Bangunan utama terdiri dari 8 lantai $(31 \mathrm{~m})$ dengan jenis struktur beton bertulang.

4. Perhitungan dan analisa struktur dilakukan dengan tiga dimensi. Beban-beban yang diperhitungkan meliputi :

a). Beban mati/berat sendiri bangunan (dead load).

b). Beban hidup (live load).

c). Beban gempa (earthquake load).

5. Analisa gaya gempa yang digunakan adalah Analisa Gempa Statik Ekivalen dan Analisa Gempa Dinamis yang dilakukan dengan analisa respon spektrum gempa zona 6 untuk wilayah Sumatera Barat.

6. Analisa gaya dalam dan deformasi dilakukan dengan menggunakan program komputer SAP 2000 (Structure Analysis Program 2000).

7. Peraturan-peraturan yang digunakan:

a). Tata Cara Perhitungan Struktur Beton untuk Bangunan Gedung (SNI -2847-2002).

b). Tata Cara Perencanaan Ketahanan Gempa untuk Bangunan Gedung (SNI -1726-2002).

c). Pedoman Perencanaan Pembebanan untuk Rumah dan Gedung (SKBI - 1.3.53.1983).

\section{ANALISA HASIL DAN PEMBAHASAN}

\subsection{Deformasi Lateral}

Dari analisa struktur didapatkan hasil deformasi lateral dengan dua titik tinjau seperti yang diperlihatkan pada Gambar 3. 


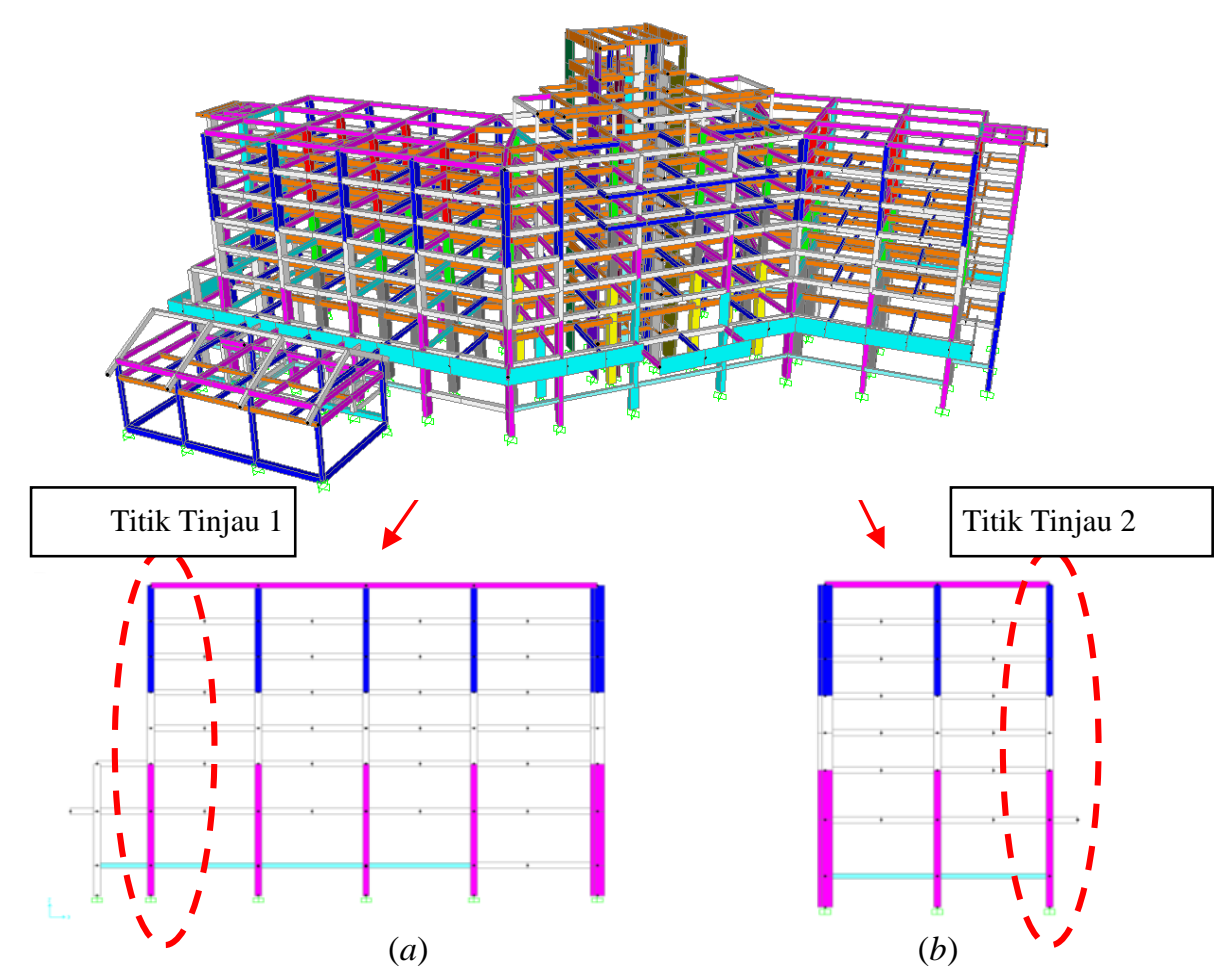

Gambar 3. Struktur Gedung Hotel Bumi Minang, (a). Titik Tinjau 1, (b). Titik Tinjau 2

Deformasi lateral titik tinjau 1 diperlihatkan Gambar 4 dan Gambar 5. Dapat dilihat bahwa semakin ke atas deformasi semakin besar seiring dengan kenaikan lantai bangunan. Perpindahan maksimum $\left(\delta_{\text {maks }}\right)$ terjadi pada lantai atap untuk masing-masing struktur bangunan baik arah $\mathrm{x}$ maupun arah y. Terdapat perbedaan deformasi yang signifikan antara struktur bangunan tipe 1 dibandingkan struktur bangunan tipe 4. Pengurangan deformasi bangunan akibat pemberian dinding geser pada bangunan sekitar $85 \%-93 \%$.

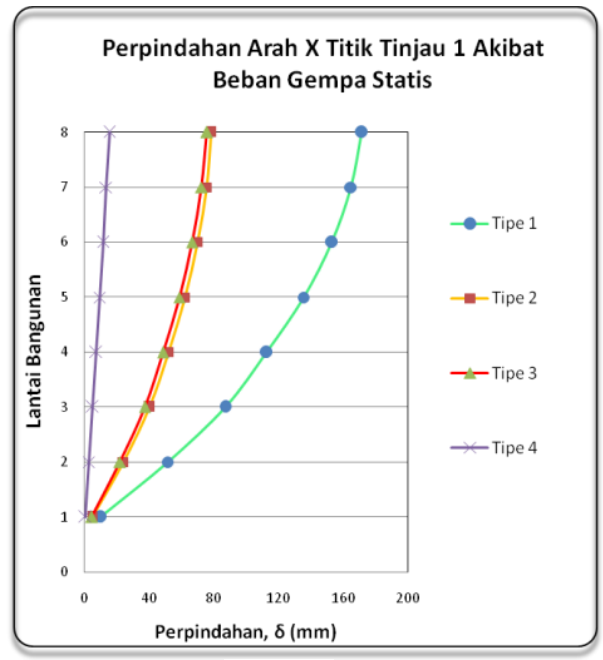

(a)

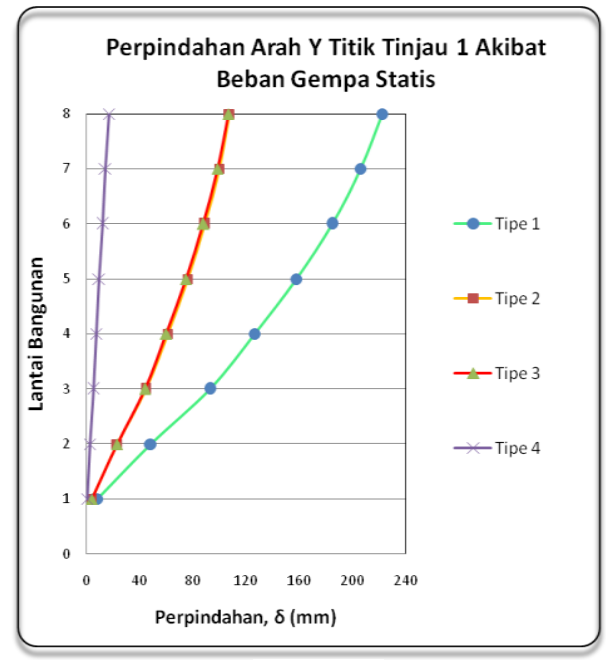

(b)

Gambar 4. Perpindahan Titik Tinjau 1 akibat Beban Gempa Statis (a) Arah X, (b) Arah Y 


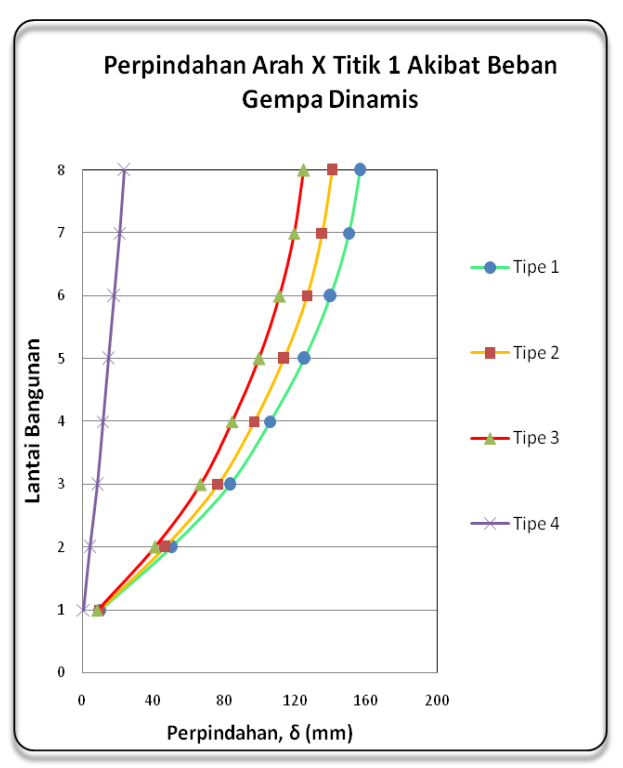

(a)

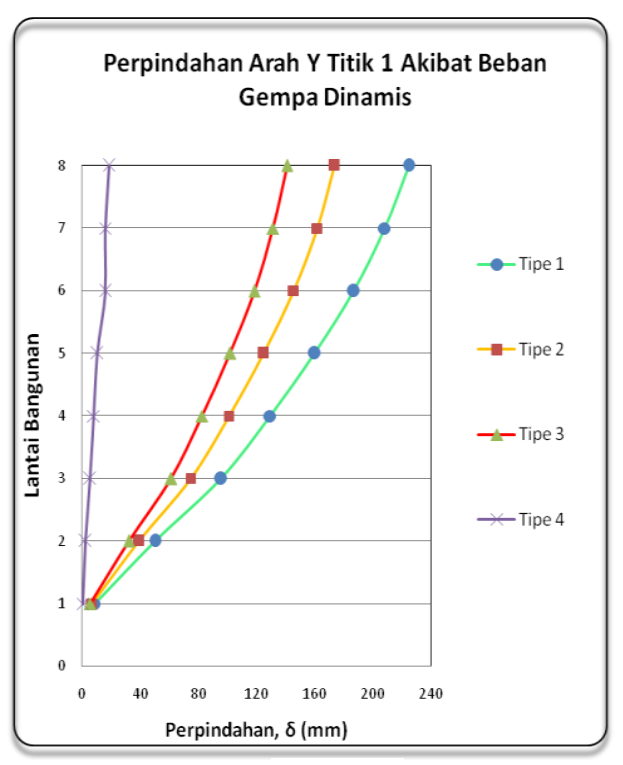

(b)

Gambar 5. Perpindahan Titik Tinjau 1 akibat Beban Gempa Dinamis (a)Arah X, (b)Arah Y

Dari grafik deformasi lateral pada titik tinjau 2 (Gambar 6 dan Gambar 7) dapat dilihat perbedaan yang signifikan terjadi pada struktur bangunan tipe 1 dibandingkan tipe 4 baik akibat beban gempa statik ekivalen maupun akibat gempa dinamis. Perpindahan maksimum terjadi pada lantai atap. Pengurangan deformasi akibat pemberian dinding geser sekitar $85 \%-95 \%$.

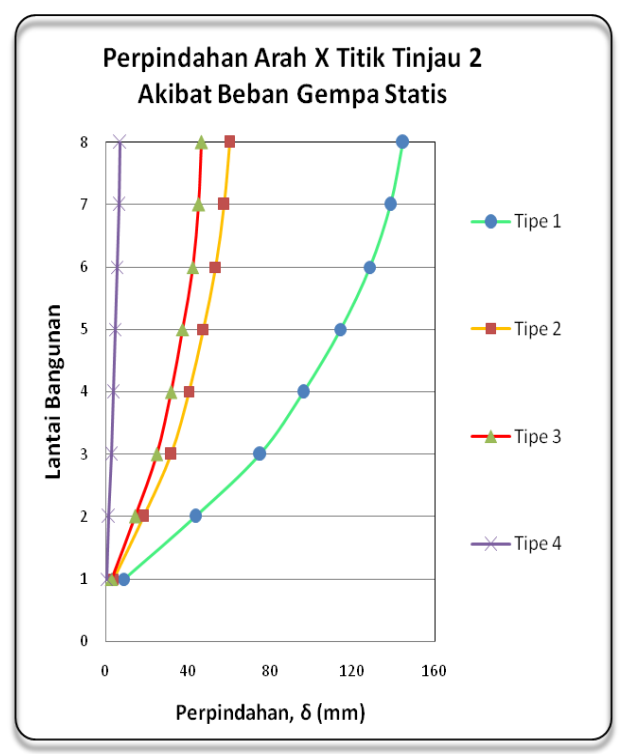

(a)

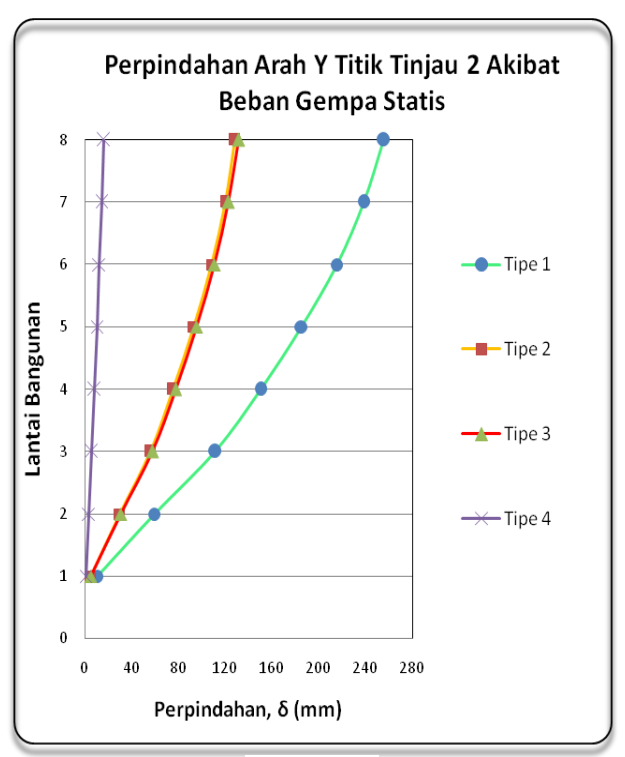

(b)

Gambar 6. Perpindahan Titik Tinjau 2 Akibat Beban Gempa Statis (a) Arah X, (b) Arah Y 


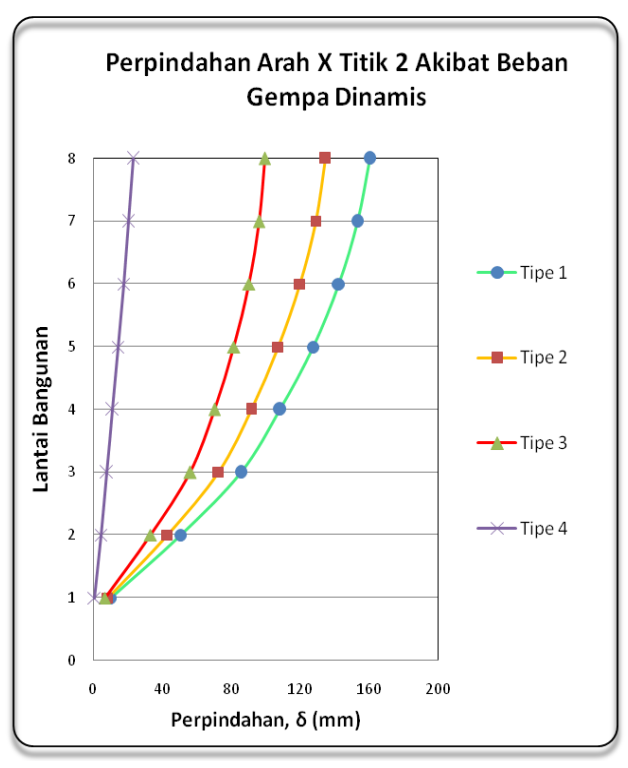

(a)

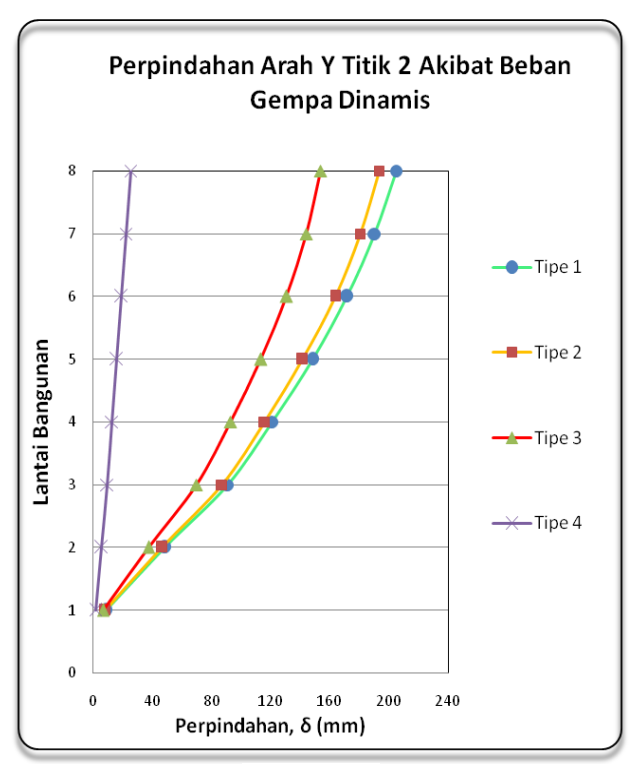

(b)

\section{Gambar 7. Perpindahan Titik Tinjau 2 Akibat Beban Gempa Dinamis (a)Arah X, (b)Arah Y}

Dari hasil deformasi yang terjadi pada titik tinjau 1 dan titik tinjau 2, dapat dianalisa bahwa perpindahan maksimum pada bangunan dengan dinding geser lebih kecil dibandingkan bangunan dengan dinding geser. Hal ini membuktikan bahwa pemberian perkuatan pada struktur bangunan berupa dinding geser dapat memperkecil perpindahan yang terjadi. Ini disebabkan dinding geser lebih bersifat kaku.

\subsection{Gaya Dalam}

Gaya dalam yang diperoleh dari hasil analisa struktur bangunan ditunjukkan oleh Gambar 8 s/d Gambar 10. Gaya aksial pada balok akibat beban gempa statik ekivalen dapat dilihat pada Gambar 8.a. Pada grafik terlihat perbedaan yang terjadi pada struktur bangunan tanpa dinding geser dibandingkan dengan struktur bangunan dengan dinding geser. Gaya aksial maksimum terjadi pada lantai 6 bangunan. Gaya aksial bangunan dengan dinding geser lebih kecil dibanding dengan bangunan tanpa dinding geser.Sedangkan gaya aksial pada balok akibat beban gempa dinamis dapat dilihat pada Gambar 8.b. Pada grafik terlihat perbedaan yang terjadi pada struktur bangunan tanpa dinding geser dibandingkan dengan struktur bangunan dengan dinding geser.

Gambar 9 memperlihatkan gaya geser pada balok akibat beban gempa statik ekivalen dan beban gempa dinamis respon spektrum. Terlihat bahwa gaya geser maksimum terjadi pada lantai 2 bangunan. Gaya geser pada bangunan dengan dinding geser lebih kecil dibandingkan bangunan tanpa dinding geser. Pengurangan gaya geser akibat pemberian dinding geser berkisar $65 \%-70 \%$. Hal ini disebabkan dinding geser memberikan kekakuan yang besar sehingga dapat menahan gaya lateral yang terjadi pada struktur.

Momen yang terjadi pada balok ditunjukan oleh Gambar 10. Dari gambar ini terlihat bahwa bangunan dengan dinding geser menghasilkan momen yang lebih kecil dari momen bangunan tanpa dinding geser. Momen maksimum terjadi pada lantai 2 dan menurun seiring kenaikan lantai bangunan. 


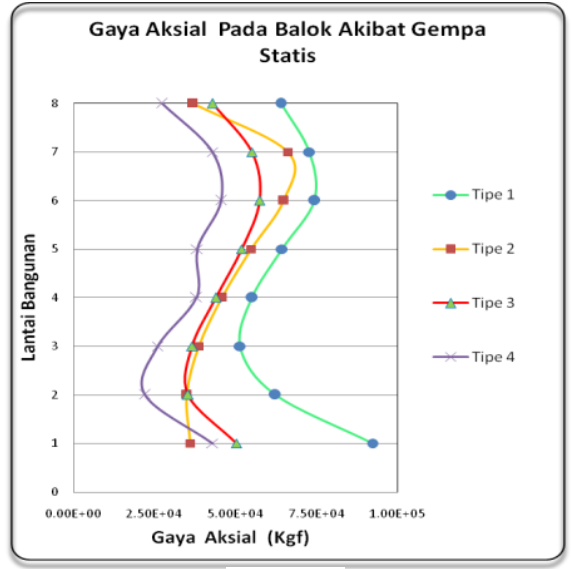

(a)

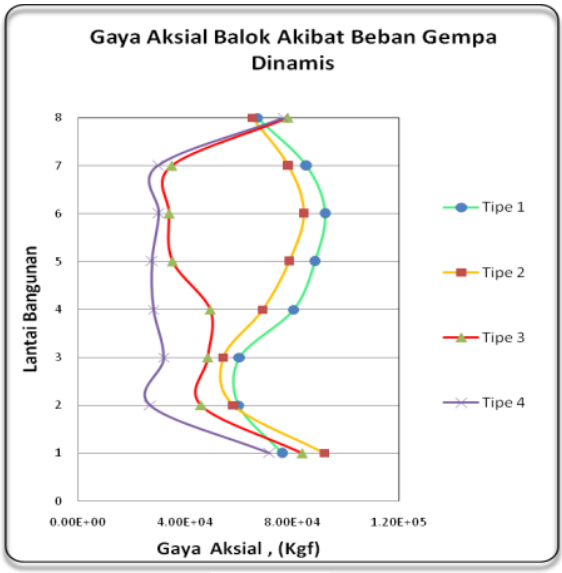

(b)

Gambar 8. Gaya Aksial Pada Balok Akibat Gempa (a) Statis, (b) Dinamis

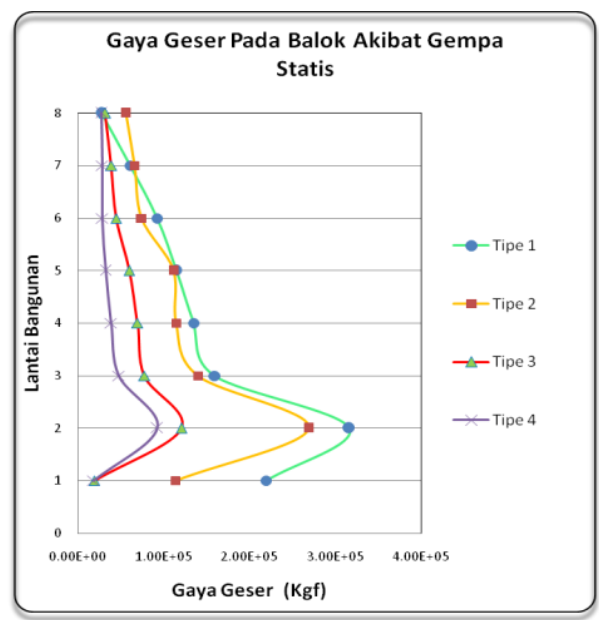

(a)

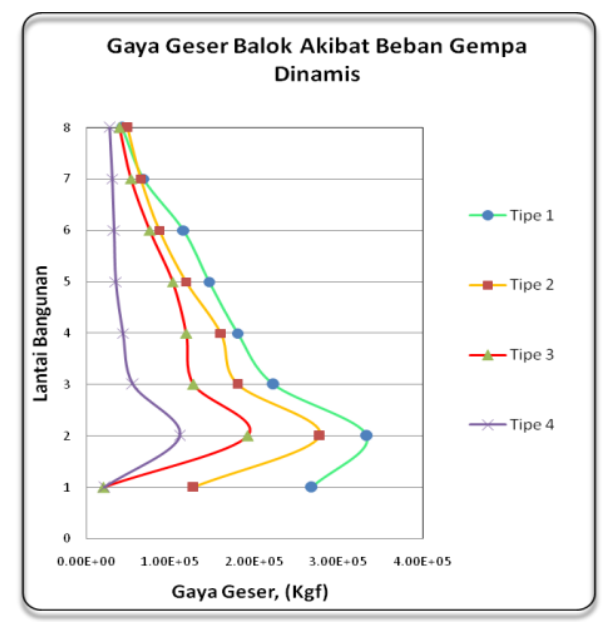

(b)

Gambar 9. Gaya Geser Pada Balok Akibat Gempa (a) Statis, (b) Dinamis

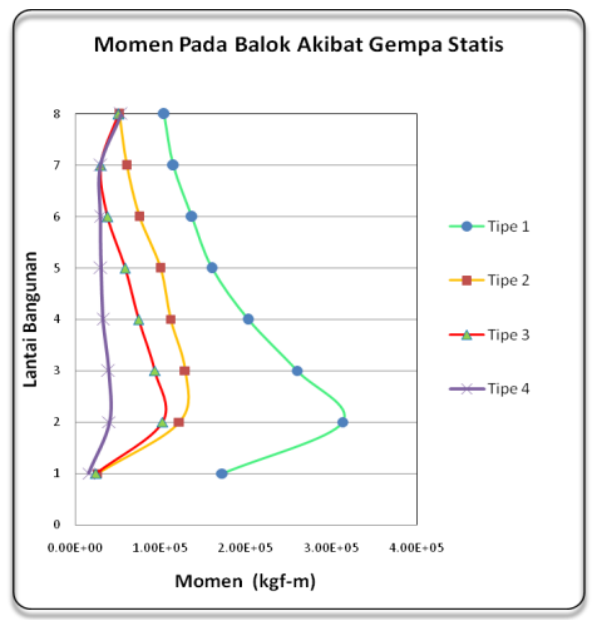

(a)

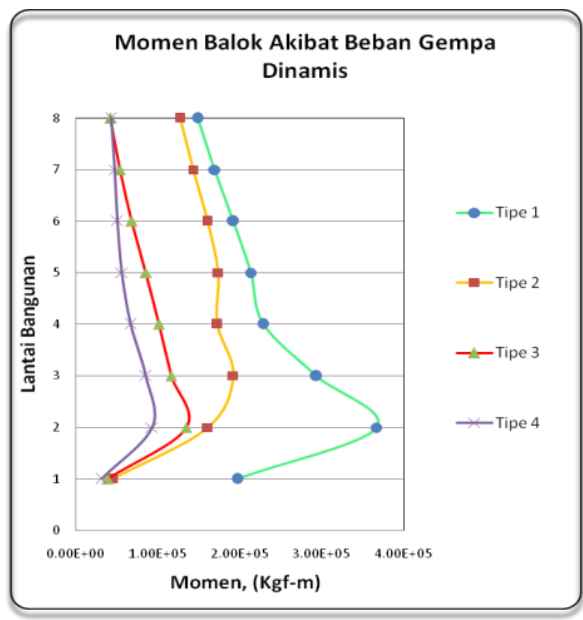

(b)

Gambar 10. Momen Pada Balok Akibat Gempa (a) Statis, (b) Dinamis 
Gaya aksial kolom ditunjukan pada Gambar 11. Gaya aksial kolom yang membebani struktur bangunan tanpa dinding geser lebih besar dari struktur bangunan dengan dinding geser.

Sama halnya dengan gaya aksial, gaya geser yang terjadi pada struktur bangunan dengan dinding geser jauh lebih kecil dari struktur bangunan tanpa dinding geser. Hal ini disebabkan dinding geser dapat menahan gaya lateral khususnya beban gempa. Pada Gambar 12 dapat dilihat bahwa gaya geser maksimum terjadi pada lantai 3 dan berkurang seiring kenaikan lantai bangunan. Pemberian dinding geser pada bangunan dapat memperkecil gaya geser yang terjadi pada kolom.

Nilai momen pada kolom sebanding dengan momen yang dialami pada balok. Nilai momen semakin kecil seiring dengan kenaikan lantai bangunan. Namun momen maksimum terjadi pada lantai 2. Dapat disimpulkan bahwa pemberian dinding geser pada struktur bangunan Hotel Bumi Minang dapat memperkecil gaya dalam sehingga lebih efisien dalam perencanaan.

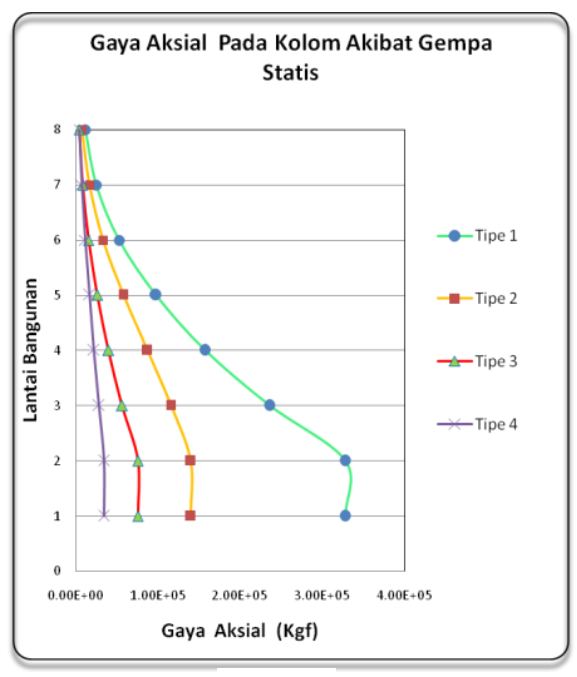

(a)

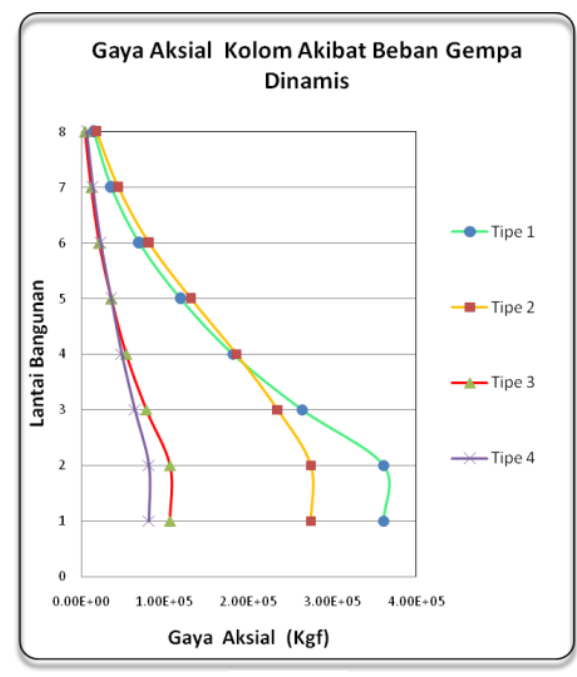

(b)

Gambar 11. Gaya Aksial Pada Kolom Akibat Gempa (a) Statis, (b) Dinamis

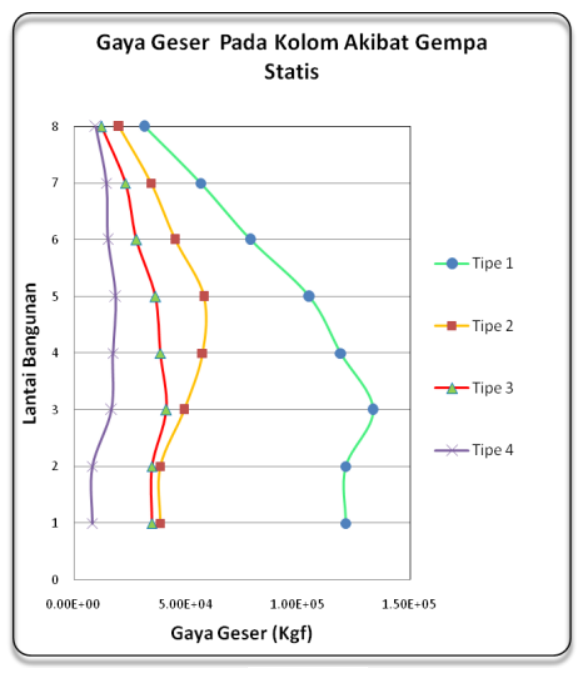

(a)

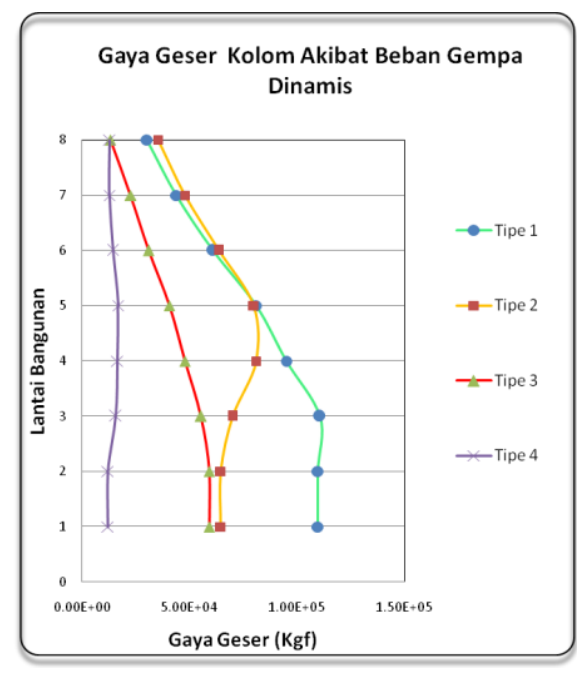

(b)

Gambar 12. Gaya Geser Pada Kolom Akibat Gempa (a) Statis, (b) Dinamis 


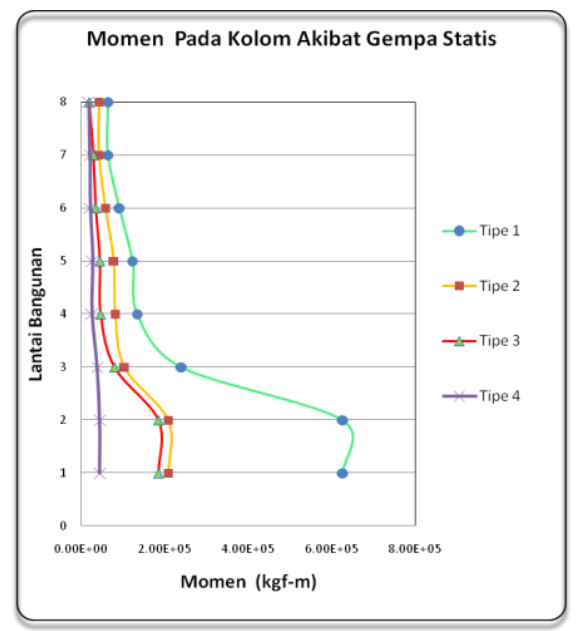

(a)

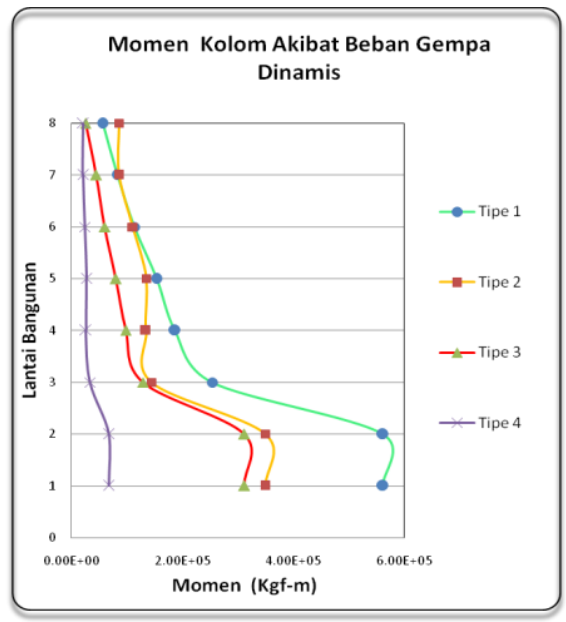

(b)

Gambar 13. Momen Pada Kolom Akibat Gempa (a) Statis, (b) Dinamis

\subsection{Kapasitas Penampang dan Kuat Geser Kolom}

Kapasitas penampang kolom bangunan dapat dilihat dari diagram interaksi P-M (Gambar 14).

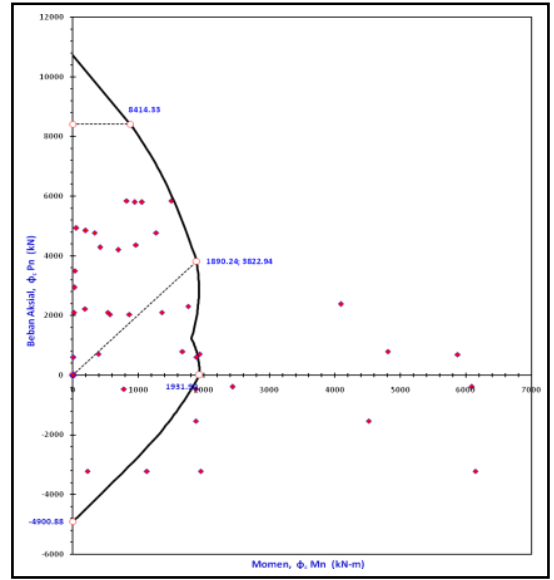

(a)

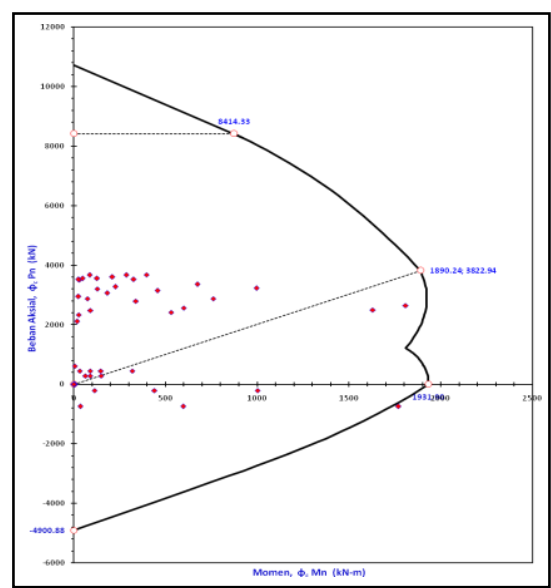

(c)

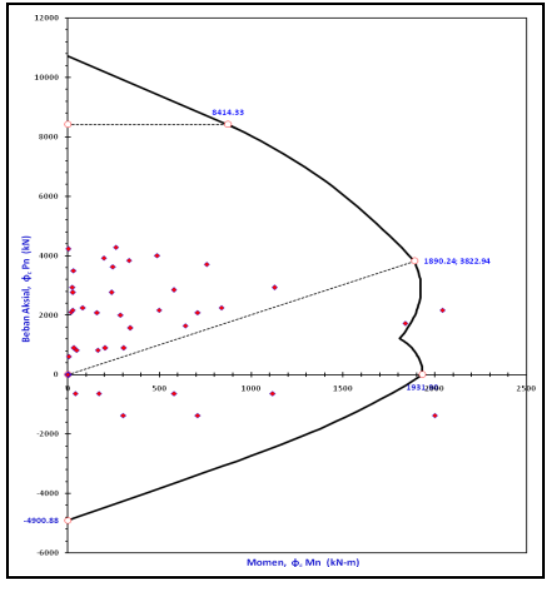

(b)

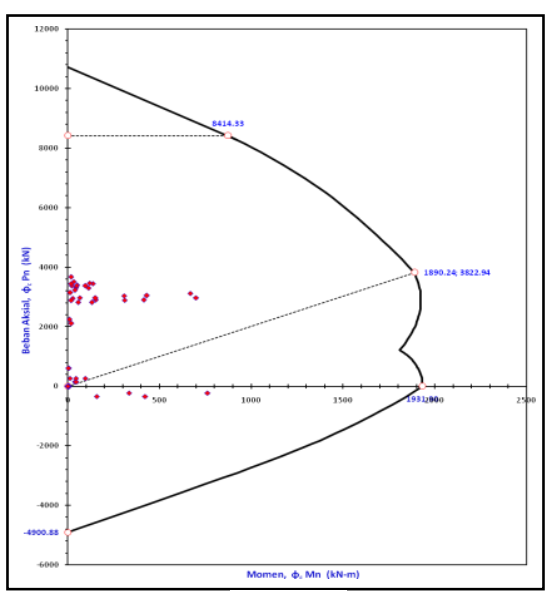

$(d)$ 
Gambar 14. Kapasitas Penampang Kolom (a) Tipe 1, (b) Tipe 2, (c) Tipe 3, (d) Tipe 4 Tabel 1. Perbandingan Kuat Geser Pada Kolom Bangunan

\begin{tabular}{|c|l|c|c|c|c|}
\hline \multirow{2}{*}{ Tipe } & Tinjauan & $\boldsymbol{V}_{\boldsymbol{r}}(\mathbf{k N})$ & $\boldsymbol{V}_{\boldsymbol{u}}(\mathbf{K N})$ & $\boldsymbol{V}_{\boldsymbol{r}} \geq \mathbf{V u}$ & Keterangan \\
\hline \multirow{2}{*}{ Tipe 1} & Tumpuan & 567,98 & 1189,10 & $567,98<1189,10$ & Tidak Ok \\
\cline { 2 - 6 } & Lapangan & 432,26 & 1189,10 & $432,26<1189,10$ & Tidak Ok \\
\hline \multirow{2}{*}{ Tipe 2 } & Tumpuan & 567,98 & 377,72 & $567,98>377,72$ & Ok \\
\cline { 2 - 6 } & Lapangan & 432,26 & 377,72 & $432,26>377,72$ & Ok \\
\hline \multirow{2}{*}{ Tipe 3 } & Tumpuan & 567,98 & 341,95 & $567,98>341,95$ & Ok \\
\cline { 2 - 6 } & Lapangan & 432,26 & 341,95 & $432,26>341,95$ & Ok \\
\hline \multirow{2}{*}{ Tipe 4 } & Tumpuan & 567,98 & 121,94 & $567,98>121,94$ & Ok \\
\cline { 2 - 6 } & Lapangan & 432,26 & 121,94 & $432,26>121,94$ & Ok \\
\hline
\end{tabular}

Dari Gambar 14 terlihat bahwa pada kapasitas penampang kolom bangunan tanpa dinding geser terdapat sejumlah titik kolom berada diluar batas diagram interaksi P - M. Dapat disimpulkan dari kerusakan yang terjadi dan analisa penampang kolom yang telah dilakukan bahwa kolom dari struktur bangunan tersebut tidak kuat memikul beban gempa maksimum yang akan bekerja pada struktur. Selain itu, jika ditinjau dari pengecekan terhadap kuat geser rencana kolom terlihat bahwa kolom bangunan tanpa dinding geser tidak mampu menahan gaya geser dibandingkan dengan bangunan dengan dinding geser seperti yang ditunjukan pada Tabel 1. Hal ini disebabkan dinding geser mampu menahan gaya lateral yang disebabkan oleh beban gempa.

\section{KESIMPULAN}

Berdasarkan analisis struktur yang dilakukan pada Hotel Bumi Minang dapat disimpulkan bahwa:

1. Penggunaan dinding geser dapat mengurangi deformasi sebesar $85 \%-93 \%$ dan gaya dalam sebesar $65 \%$ - 70\% dibandingkan bangunan tanpa dinding geser.

2. Penempatan dinding geser di tengah lift dan di sudut sekeliling bangunan seperti pada tipe 4 sangat baik dibandingkan dengan kondisi exsisting (dinding geser di daerah lift sampai lantai 2) dalam mereduksi deformasi dan gaya dalam.

3. Penggunaan dinding geser seperti tipe 4 sangat direkomendasikan untuk perkuatan struktur pada Hotel Bumi Minang.

\section{DAFTAR PUSTAKA}

Adrayazi, Elan, (2006), "Disain Ulang Struktur Dinding Geser Asrama Mahasiswa Unand", Tugas Akhir Strata 1, Universitas Andalas, Padang.

Paulay, T., and M.J.N. Priestley, (1992), "Seismic Design of Reinforced Concrete and Masonry Buildings", Jhon Willey \& Sons.

Park, R., and Paulay, T., (1975), "Reinforced Concrete Structures", Jhon Willey \& Sons.

Raya, Rina Mustika, (2006), "Perbandingan Pemakaian Tulangan pada Hybrid Structure (Metode Dual System) dengan Struktur Portal Biasa", Tugas Akhir Strata 1, Universitas Andalas, Padang.

SNI 03-1726-2002, Tata Cara Perencanaan Ketahanan Gempa Untuk Bangunan.

SNI 03-2847-2002, Tata Cara Perhitungan Struktur Beton Untuk Bangunan Gedung.

Wahyudi, L., (1999), "Struktur Beton Bertulang", Gramedia, Jakarta. 